\title{
Implementation and Effectiveness of Performance Management System in Alfalah Bank
}

\author{
Farheen Mughal \\ Department of Management Sciences \\ The Islamia University of Bahawalpur \\ Farheenmughal@hotmail.com
}

FaizaAkram

Department of Management Sciences

The Islamia University of Bahawalpur

Faiza0747@yahoo.com

\begin{abstract}
Syed Sadaqat Ali (Corresponding author)
Department of Management Sciences

The Islamia University of Bahawalpur

Sadaqatali.syed786@gmail.com
\end{abstract}

Accepted: December 21, 2014

Doi:10.5296/jpag.v4i4.6869 URL: http://dx.doi.org/10.5296/jpag.v4i4.6869

\begin{abstract}
Purpose: The basic purpose of this study is to provide edge to organization by providing practical solutions and recommendations so that firms can choose the best option. And in this way they can improve their evaluation system. This research is done to highlight the importance of performance management and also to study scope and effectiveness of performance management system in Alfalah Bank.

Methodology: Qualitative research methodology has been used by researcher. Through this qualitative technique data is collected and analyzed. To identify the PM issues structured interviews were conducted from the employees related with different departments of Alfalah Bank.
\end{abstract}


Findings: The research findings have shown that the employees of Alfalah bank have facing the problem of dissatisfaction from their current performance management and also the current performance management system of Alfalah bank lacks motivation and proper reward system. So for resolution of these issues researcher has recommended direction and guidelines to improve the performance management system.

Practical implications: This research can be used by HR managers for identification and resolution of issues related to evaluation of employees. The current study can be used for further research and also become the basis to provide literature review for future research.

Significance: Through this study reader can critically analyze the improvement in performance management Practices. This study shows the practical implications of recommended practices in actual business situations. This study has explored the issues (weaknesses) related with performance management in banking sector. Also the recommendation and suggestions are provided. On the basis of this study other organizations will also get the direction and guidelines to improve the performance management.

Keywords: Performance management, Reward system, PM practices, Dissatisfaction.

\section{Introduction}

In an organization the performance management has great importance for attaining competitive edge as it is considered the back bone of Human Resource Management. There are no sound facts about the actual emergence of performance management and its review techniques. The first PM was introduced before World War 1 for scoring the performance of army officers (Armstrong \& Baron, 2005). Graphic rating scale was the technique through which the performance was measured on the basis of different traits in 1920 (Stafylarakis\& Eldridge, 2002). But the weakness of this technique was that it dealt with personal attributes of employees.

Each organization has its unique mission, vision, goals and objectives. To accomplish these goals and objectives it is necessary to make plans and strategies. The most important thing is that to measure and evaluate the performance of employees so that it can be notified whether these goals are achieving according to defined strategies or not. The performance of people is directly related to performance of organization.

Performance management provides the way to managers to overcome and improve the sudden changes very soon (Cokins, 2004). Bascal (1999) defines that PM is the continuous process of job activities, employee participation in goals achievement and feedback from management.

The purpose of this current research is to identify the issues related with implementation of performance management. It also shows the effects of this system and defines the communication between higher and lower management through evaluation process of performance management. As in banking sector the performance management system is still manual that does not give proper results.

The basic purpose of this study is to provide edge to organization by providing practical solutions and recommendations so that firms can choose the best option. And in this way can ion improve their evaluation system. In this study Alfalah bank is taken for discussing the issues related to its performance management. Also the effects before and after implementing performance management are also observed. 
Armstrong (2006) stated that the purpose of PMS is actually the establishment of such a culture in which performance improvement of processes and skills of all employees is noticed. The aim of this practice is to remove the deficiency that was found in previous systems. Business performance can be improved through PMS.

Now the banking sector in Pakistan making significant progress from few years and all this is due to privatization of banks. There are many banks in Pakistan which make significant contribution in GDP of Pakistan. Alfalah bank is operating its operations in 70 big cities of Pakistan. In Alfalah bank there are 6453 employees who are performing well. Like other organizations Alfalah bank has also its proper performance management system through which it measure and evaluate the performance of not only employees but also of whole branch. The performance management system in Alfalah bank is based on rating and deposit mobilization. The performance is measured on both individual and whole branch performance basis.

This study has explored the issues (weaknesses) related with performance management in banking sector. Also the recommendation and suggestions are provided. On the basis of this study other organizations will also get the direction and guidelines to improve the performance management. Banks focus on measures that are best and proper in providing fair results. As due to privatization and strict rules Pakistani banking industry is changing its HR policies. For attaining high level of performance significant correction and action are taking by banking sector (Richard and George, 2006).

Now for more progress different strategies and policies related to HR are making. Banks focus on measures that are best and proper in providing fair results.

\section{Literature Review}

Each organization has its unique mission, vision, goals and objectives. To accomplish these goals and objectives it is necessary to make plans and strategies. The most important thing is that to measure and evaluate the performance of employees so that it can be notified whether these goals are achieving according to defined strategies or not. The performance of people is directly related to performance of organization. This process of measuring performance is related to performance management.

As according to Prasad (2005) performance management is the systematic process of planning and appraising performance by providing timely feedback and guidelines to employees for the enhancement of their performance. And the performance appraisal is the crucial part of performance management. Performance management is the process of enhancing the performance of organization through individual and team performance (Armstrong 2006). The basic purpose of performance management is to align the individual performance with organizational goals and objectives (Desselor 2008). From the last fifteen years, the organizations mostly call their appraisal system as performance management system (Pareek and Rao, 2006).

As Aguinis (2007) states performance management is basically related with finding out weaknesses their improvement and establishment of performance of individual. He also states that this process includes the alignment of vital goals with individual performance and proper feedback. Performance management provides the way to managers to overcome and improve the sudden changes very soon (Cokins, 2004). Bascal (1999) defines that PM is the continuous process of job activities, employee participation in goals achievement and feedback from management.

In an organization the performance management has great importance for attaining competitive edge as it is considered the back bone of Human Resource Management. There are no sound facts about the actual emergence of performance management and its review techniques. The first PM was introduced before worldwar 1 for scoring the performance of army officers (Armstrong \& Baron, 2005). Graphic rating scale was the technique through which the performance was measured on the basis of different traits in 1920 (Stafylarakis\& 
Eldridge, 2002). But the weakness of this technique was that it dealt with personal attributes of employees.

In 1940, another technique Annual confidential report (ACR) written by supervisor about employee once in a year was set up. The main drawback of this report was that as there was no participation by employee so no feedback was given by management which leads towards no improvement and betterment in performance (Stafylarakis\& Eldridge, 2002).

To minimize the disadvantages of graphic rating technique another method Management by Objectives was offered. The main purpose of this practice is to review the performance of managers. Through this practice it is observed whether managers are completing their assigned tasks and objectives or not. On the basis of this report future goals and targets are decided and need for improvement was also identified (Greer, 2001). According to Walters (1995) MBO is continuous process to realize the managers about concerned expectations. MBO basically emphasizes on the end results not on job traits and behaviors.

According to Weihrich and Koontz (2005) MBO is just important for attaining the goals. After MBO, in 1970 another practice performance appraisal was introduced. The main purpose of this approach is to provide the feedback to every employee so that performance deficiencies can be improved. In 1970s and 1980s according to Armstrong \& Baron (1998) it was found that performance appraisal was not considered as compulsory part of management process. After all above approaches performance management system was developed and introduced.

Armstrong (2006) stated that the purpose of PMS is actually the establishment of such a culture in which performance improvement of processes and skills of all employees is noticed. The aim of this practice is to remove the deficiency that was found in previous systems. Business performance can be improved through PMS. This practice allows businesses to review business vision, increase motivational level, focuses on not only individual but also on organizational development and improvement. PMS is related with self monitoring process. Different PM frameworks are offered by different writers.

Due to intense market competition businesses are focusing towards becoming more efficient and effective. Now organizations are developing and implementing the performance management system according to their culture. Basic key elements of PM are planning, monitoring and rewards. For more productivity it is necessary to identify the performance of individuals and provide improvement measures.

There are two basic purpose of PMS 1.decision making 2. Employee development. In PMS decision making and appraisal system is used for the purpose of pay increment, promotions, transfers, assignments and decrease in work force. While in case of employee development the appraisal system works for training, job experience, monitoring and other development activities.

Competency model is used by organizations as a proper tool for performance management system. Competency model is related with the measurement of skills, knowledge and abilities. For implementing effective PMS employees should be evaluated on relevant job factors in this way it can be estimated that on what level the organization is. The main purpose of developing PMS is to provide motivation for managers.

Beer and Ruh (1976) introduced the term performance management. The basic aim of this system was to help the managers for the use of perfect and integrated performance appraisal and reward system. According to Armstrong ( 2001) previous performance and appraisal system were not so reliable as they were not providing the true and fair results. Now in recent environment the competition and stress changes are increasing so organizations are looking forward for effective PMS (De-Waal, 2007).

For attaining better results PMS is more effective technique than any other. So it is useful approach to align competitive edge with organizational goals is PMS (Lawler, 1998). In sudden and dynamic environment PM is the best fit to provide desired results (De-Waal, 
2006).

PMS is the organizational tool that is related with evaluation, execution and improvement of organizational performance. PM helps in making strategies and provides easy way to employees for future insights. Through this process the employees learn how they can think strategically and make strategic decisions (Marr, 2006). As competition is increasing and for successful existence it is necessary for the organizations to have competent employees who can struggle in uncertain environment with increasing output. Motivation is the main variable that enhances the performance of employees and indirectly affects the performance management. Basically the efficiency of employees can be reduced if motivation factor is not applied in organization. So for increasing the performance and motivation it is necessary to offer performance related compensation (Delaney and Huselid, 1996).

For all organizations it is first priority to enhance the performance of not only employees but also the performance of whole organization. Performance management works as a bridge between the organizational strategies and results (Bhatia, 2006). According to Potgieter (2005) the performance management is the latest concept of performance appraisal in which it is observed that how an employee perform his assigned tasks whole the year. This review may be annually, semi annually and quarterly base. He also describes that through performance management the future objectives of an employee can be decided. Performance management system provides the information related with salary, compensation plans, feedback, employees strength and weaknesses. Basic objectives of performance management are to use the information obtained through PMS in making decisions of strategic, administration, information, developmental, organizational maintenance, and documentation.

\subsection{Strategic Objectives:}

To make organizational level strategies is the basic aim of performance management system. Performance management system align the goals of organization with individual goals this thing make individual more engage towards goals attainment.

\subsection{Administration Objectives:}

To provide more information about administrative decisions performance management system is the best way. In administrative decisions salary increment, retention, termination, recognition of individual performance, identification of poor performers and reward system are discussed on the basis of that information obtained from performance management system.

\subsection{Information Objectives:}

Through performance management system communication gap can be removed. As top management inform the employees about their performance and also guide them to work more properly. In case of any weakness in employee, top management try to remove these by communicating with them and also by providing training to them. Top management also inform employees that what type of expectations they have from employees.

\subsection{Developmental Objectives:}

The feedback provided by management is also used for developmental purposes. Managers may use feedback for identifying the weaknesses of employees. This information is then can be used to coach employees for improvement of performance. Through developmental objectives the employees can select their career paths. In this way they attain the proper guidance about their field in which they want to work.

\subsection{Organizational Maintenance Objectives:}

For the work force planning it is necessary to have all information about performance of individuals and organization. In workforce planning the need of employees in and outside organization, to identify the priorities, proper allocation of human resource are included and all these planning are done on the basis of performance management system. In work force 
planning the skills, abilities, knowledge and job traits are identified.

\subsection{Documentation Objectives:}

Information gathered from performance management system is used for documentation objectives. Documentation is necessary for some personnel decisions. Documentation helps to store data that become the basis of future decisions. On the basis of documentation future goals and strategies are planned.

\section{Characteristics of Performance Management System}

There are some characteristics of performance management due to which an organization achieve its objectives.

\subsection{Strategic Congruence:}

Performance management system should be designed and implemented in such a way that the purpose of alignment of unit goals with organizational goals is achieved.

\subsection{Thoroughness:}

It means system should be complete and through regarding following dimensions. It should evaluate all employees including managers. It should evaluate all job responsibilities and the performance management system should be detailed and for whole review duration. Feedback must be provided for improvement purpose.

\subsection{Practicality:}

System always should be least expensive, less complicated and less time consuming otherwise it will not give better and fair results. This type of system gives more benefits to those who take decision on the basis of information obtained from this system. Performance management system provides the benefits of performance enhancement, job satisfaction and motivation so its results productivity, output and profits should be positive.

\subsection{Meaningfulness:}

Performance management system should be understandable it should meet the standard of system while implementing it. Evaluation during implementation should be relevant and specific. Evaluation should not be on annual base .Quarterly base evaluation in system provide more productive results.

\subsection{Specificity:}

It means system should provide brief but complete information about performance evaluation and measurement. It should provide complete guidance about the expectations of managers from employees.

\section{Identification of effective and ineffective performance}

It means system should be designed and implemented in such a way that it should point out weaknesses of system. In this way proper results can be obtained. In proper designed system, the evaluation is on the basis of rank and level of performance.

\subsection{Reliability:}

System should contain tools that derive consistent results. Tools that are used for performance measurement and evaluation should provide error free results.

\subsection{Acceptability and fairness:}

Performance management system should be acceptable and fair by all. If there is any error between work and evaluation then it is assumed that system is not fair and its results are not authentic and reliable. 
5. Scope and effectiveness of performance management system in the Banking industry of Pakistan

Individual performance is measured and evaluated by performance management system (Klootand Martin, 2000). To measure the individual and team performance the performance management is the broadly used system. Performance evaluation and measurement is considered as most important part of economies (Hindustan Times, 2001). In Pakistan it became necessary to develop and implement performance management system due to some reasons. For better performance and to make uniqueness in strategies performance management system is compulsory (Cardy and Dobbins, 1994; Marquardt and Engel, 1993; Smither, 1998). In Pakistan and all other developing countries employees are not involved in whole performance measuring and evaluation process (Mendonca and Kanungo, 1990; Virmani and Guptan, 1991). Performance management system in Pakistan has been promoting for last decade. At high level for the business growth specificstandard are set to meet the expected performance. So organization then tries to meet these standards to gain competitive edge on horizontal level. Banks focus on measures that are best and proper in providing fair results. As due to privatization and strict rules Pakistani banking industry is changing its HR policies. For attaining high level of performance significant correction and action are taking by banking sector (Richard and George, 2006).

Now for more progress different strategies and policies related to HR are making. Banks focus on measures that are best and proper in providing fair results. As due to privatization and strict rules Pakistani banking industry is changing its HR policies. For attaining high level of performance significant correction and action are taking by banking sector (Richard and George, 2006).

Banks focus on measures that are best and proper in providing fair results. As due to privatization and strict rules Pakistani banking industry is changing its HR policies. For attaining high level of performance significant correction and action are taking by banking sector (Richard andGeorge, 2006). Now for more progress different strategies and policies related to HR are making. Farr (1993) explains that daily base feedback is better than annual feedback because it is related with qualitative data (attitude, behavior etc). Day to day feedback process provide the better way to align performance standards between employees and organizations (Taylor et al., 1984).

In Pakistani banking industry as the role of bureaucrats is prominent so participation from employees in performance evaluation and appraisal system is not involved and counted (Barlow, 1989; Newton and Findlay, 1996; Townley, 1993). The basic purpose of this study is that Pakistani banking industry is moving towards progress and getting advantages from current performance system. Due to nationalization of banking sector in Pakistan and greater participation of Bureaucrats the system was not so effective for performance management but now after privatization, banking industry in Pakistan is introducing the proper performance management system. This system is becoming more prominent in creating effectiveness. But as Pakistan is developing country and here new systems are not easily implemented and appreciated so there is need to analyzed it critically. According to Armstrong and Baron (1998) for fair and accurate results it is necessary the system that is implemented should be fair.

\section{Performance management system and its impact on the employees of Bank Alfalah}

After independence the banking sector of Pakistan was not so developed. Now the banking sector in Pakistan making significant progress from few years and all this is due to privatization of banks. There are many banks in Pakistan which make significant contribution in GDP of Pakistan. Alfalah Bank is one of the most popular banks corporate in 1997. And later like other banks it was privatized. Now Alfalah bank is operating its operations in 70 big cities of Pakistan. In Alfalah bank there are 6453 employees who are performing well.

Like other organizations Alfalah bank has also its proper performance management system through which it measure and evaluate the performance of not only employees but also of 
whole branch. The performance management system in Alfalah bank is based on rating and deposit mobilization. The performance is measured on both individual and whole branch performance basis. If the performance rating is satisfactory and excellent then outcome of appraisal would be positive and bonuses (rewards) are provided on the basis of rating. If outcome comes negative due to low and weak performance then improvement measures are taken on the need base. In performance management system the appraisal is done on the appearance, attitude, behavior and personality base. The criteria of positive appraisal are predefined. Total scores are 100. If obtained are 60 then $\mathrm{C}$ rate is given, if $60-70$ then $\mathrm{B}$ rate, if 70-80 then A rate and if 80-100 then A+ is assigned. This report is sent to area office then to Human resource department after the approval of CEO. Then a feedback letters are sent to employees in whom bonuses, increment etc on the basis of rating performance are written.

Performance management system in Alfalah bank motivates the employees for more productive tasks. Reward system in bank increase the efficiency and effectiveness if employees. Feedback provide employees a guideline through which they can judge their performance and make proper improvements.

\section{Research Objectives}

The main objectives of this study are

- To highlight the importance, role and characteristics of performance management in an organization.

- To study scope and effectiveness of performance management system in Pakistani Banking sector.

- To describe the performance management system and its impact on the employees of Bank Alfalah.

\section{Research Design}

Basically the main objective of this research is to discover the weaknesses of current performance management system in an organization that hinders the proper implementation of this system. In methodology for new research qualitative research approach is used. As this research is based on qualitative data and provide better results for analysis ( (Aslam \& Sarwar, 2010).

\subsection{Research Strategy:}

I have selected Alfalah Bank for achieving the basic objective of research. Alfalah Bank is one of the most popular banks corporate in 1997. And later like other banks it was privatized. Now Alfalah bank is operating its operations in 70 big cities of Pakistan. In Alfalah bank there are 6453 employees who are performing well Alfalah bank has a its proper performance management system through which it measure and evaluate the performance of not only employees but also of whole branch. The performance management system in Alfalah bank is based on rating and deposit mobilization. The performance is measured on both individual and whole branch performance basis. In the methodology, to explore a problem it is better to choose interview technique. So I have selected the interview tool for population to gather relevant data of performance management. I select population for interview tool as there are total 7 members in bank Alfalah that are limited which is not suitable for sample size.

\subsection{Research Method:}

Preliminary, data was collected from secondary sources. Later by using semi structured interview tool open ended questions were asked from 7 employees of Bank Alfalah in which respondents of middle management and subordinates were included. The main purpose of interviews was to cover the gap between current and proposed performance system and to find out issues related to Performance management system and also its effects on employees. 


\section{Interview Questions}

- Is your Bank use any performance appraisal system?

- How many times performance appraisal is conducted by bank for employees?

- Who is responsible for conducting the performance appraisal?

- Is performance appraisal form different or same for all employees?

- Are all members involved in setting the standards for measuring the performance?

- How much a manager involve in performance appraisal system?

- Are the employees are satisfied with the criteria used by managers in performance appraisal process?

- Is this process is beneficial or not? If yes then how?

- Is management provide any support and help for improvement after feedback?

- What are the weaknesses and strengths of your performance appraisal system?

- Is it possible to make professional development through current appraisal process?

- Is manager trained in providing feedback to employees?

- Is your current system making any contribution in motivating employees?

- Are employees informed with the purpose of performance appraisal process?

\section{Data Collection and Analysis}

Interview technique is used in measuring and evaluating the performance management system in Alfalah Bank. Data was gathered through interview questions. Questions were asked from managerial and non managerial staff. As the interview was consisted of 14 questions and the population of this study was 7 employees. Employees were selected from different departments of Bank. Consistency this technique was checked through content analysis.

\subsection{Content Analysis:}

As the first question was

- (Is your Bank use any performance appraisal system?) As the Bank was using the performance appraisal system so all respondents gave the same answer of this question.

- (How many times performance appraisal is conducted by bank for employees?) All respondents answered that the evaluation and performance measurement is done on yearly basis.

- (Who is responsible for conducting the performance appraisal?) Out of 7, 4 respondents told that performance appraisal is conducted by Human Resource department while remaining 3 respondents answered that appraisal is conducted by Branch manager and higher authority.

- (Is performance appraisal form different or same for all employees?) 2 respondents out of 7 answered that the forms are different used for performance appraisal. One respondent said that, "Forms vary with job description but based on performance of each employee". Another employee said that, "it may be different based upon their performance because all employees are not performing the same job". Remaining 5 respondents answered that same form is used for all employees. 
- (Are all members involved in setting the standards for measuring the performance?) 4 respondents out of 7 answered that yes all members or employees are involved in setting standard for measuring performance. One employee said that, "every employee opinion is taken at the time of setting standard". 3 respondents told that employees are not involved in setting standard. One employee told, "Only higher management is involved in setting standard for performance management system". Another respondent stated that only human resource department of any organization set the standard of performance measuring system.

- (How much a manager involve in performance appraisal system?) In response of this question all respondents said that manager's involvement in performance appraisal system is nearly 70 to $80 \%$.

- (Are the employees are satisfied with the criteria used by managers in performance appraisal process?) Respondents said that majority of employees are satisfied with this system but one respondent told that it depends on the rewards given to employees according to performance.

- (Is this process is beneficial or not? If yes then how?) Five respondents answered, "Yes this process is beneficial for both employee and organization as it make employee more hardworking". Two respondents said this system is not beneficial as it is not a valid and reliable system at some stages favoritism take place.

- (Is management provide any support and help for improvement after feedback?) All respondents answered that management provide support and help for improvement in performance after feedback.

- (What are the weaknesses and strengths of your performance appraisal system?) Weaknesses: cannot measure exactly performance, based on favoritism, appraisal by manager just, once in a year, unable to measure performance.

- Strengths: make employees more efficient, give chance to work hard, HR take active part in this process, create competition among employees.

- (Is it possible to make professional development through current appraisal process?) Two respondents answered that through appraisal process it is not possible to make professional development. Five respondents said it become more beneficial to make professional development. One respondent out of five said, "It is possible to make professional development because it provides the guidelines to improve the weaknesses".

- (Is manager trained in providing feedback to employees?) Allrespondents answered that yes managers are trained in providing proper feedback to employees.

- (Is your current system making any contribution in motivating employees?) Two respondents said, "This process motivates the employees and boost up them for more hard work".

- (Are employees informed with the purpose of performance appraisal process?) All respondents are informed about the purpose of performance appraisal process. One respondent said, "Employee is well aware about the purpose and importance of performance appraisal process".

\section{Conclusions}

This research is related with the study of current performance management in Alfalah bank. The purpose of this study is to identify the weaknesses and draw backs of current performance management and also to provide recommendation for more improvement. Alfalah Bank is one of the most popular banks. It was corporated in 1997. And later like other banks it was privatized. 
This study has explored the issues (weaknesses) related with performance management in banking sector. Also the recommendation and suggestions are provided. On the basis of this study other organizations will also get the direction and guidelines to improve the performance management. The research findings have shown that the employees of Alfalah bank have facing the problem of dissatisfaction from their current performance management. This research shows that the performance management of Alfalah bank lacks motivation and proper reward system. Performance management system is properly implemented in Alfalah but employees should be involved in setting standards of performance management to evaluate the performance of each employee. Also the appraisal form and other evaluating tools must be according to employee job and responsibilities.

\section{Recommendations}

Usually performance management system is developed by considering the opinions of both employees and management. Through this system performance of employees is evaluated by rating their performance that base on the activities performed by them.

There are some recommendations to improve the performance management process and system Alfalah bank so that effective and productive results can be obtained.

- Currently, Alfalah bank is using the old and traditional performance management system it should be computerized so that biasness can be removed. As by using traditional performance management favoritism and nepotism become hurdle for achieving fair results. Computerized performance management is linked with other branches through net that make possible to compare employee's performance with each other.

- Bank should this performance management for motivation purpose. Through this system employees with high scores should be rewarded in such a way that other employees are motivated to achieve the targets.

- Employees with low performance should be encouraged and trained to improve their performance.

- Feedback must be provided so that employees can align their individual tasks with organizational goals and objectives.

- Performance management process should be conducted after six months because due to yearly basis chances of errors and mistakes can be increased.

- Employees should be involved in evaluation process so that they can improve their performance to achieve set standards.

- Evaluation must be on both bases qualitative and quantitative.

- Performance management should provide direction to employees towards career development.

- Performance appraisal form should not the same for all employees. It should be according to department, tasks, nature of job and responsibilities.

\section{References:}

Aguinis, H., \& Pierce, C. A. (2008). Enhancing the relevance of organizational behavior by embracing performance management research. Journal of Organizational Behavior, 29(1), 139-145.

Armstrong, M. Armstrong's handbook of human resource management practice: Buy now from Kogan Page.

Armstrong, M. (2003). A handbook of human resource management practice: Kogan Page Limited. 
Armstrong, M., \& Baron, A. (2005). Managing performance: performance management in action: CIPD Publishing.

Aslam, H. D., \&Sarwar, S. Improving performance management practices in IT firms of Pakistan. Journal of Management Research, 2(2).

Barlow, G. (1989). Deficiencies and the perpetuation of power: latent functions in management appraisal. Journal of Management Studies, 26(5), 499-517.

Bascal, R. ((1999). Performance Management.

Cardy, R. L., Dobbins, G. H., \& Ferris, G. R. (1994). Performance appraisal: Alternative perspectives: South-Western Publishing Company.

Cokins, G. (2004). Performance management: Finding the missing pieces and closing the intelligence gap: Australia: John Wiley and Sons.

De Waal, A. A., \&Coevert, V. (2007). The effect of performance management on the organizational results of a bank. International Journal of Productivity and Performance Management, 56(5/6), 397-416.

Engel, D. W., \& Marquardt, M. J. (1993). Global Human Resource Development: Englewood Cliffs: Prentice-Hall, Inc.

Harmon, J., Scotti, D. J., Behson, S., Farias, G., Petzel, R., Neuman, J. H., et al. (2003). Effects of high-involvement work systems on employee satisfaction and service costs in veterans healthcare. Journal of Healthcare Management, 48(6), 393-405.

Jaffari, A. R., Shah, S. S. H., Aziz, J., Waris, S., Ejaz, W., Fatima, M., et al. Achieving Effective Performance Management Through Hr Systems and Performance Factors Linkage: in Perspective of Pakistani Banks. Asian Journal of Business Management, 4(2), 130-135.

Kanji, G., \&Moura E SÃ $i$, P. c. (2007). Performance Measurement andBusiness Excellence: The Reinforcing Link for the Public Sector. Total Quality Management and Business Excellence, 18(1-2), 49-56.

Khaleelur Rahman, A. A study on human resource management practices in select software units in Tamilnadu.

Koontz, H., \&Weihrich, H. (2006). Essentials of management: Tata McGraw-Hill Education.

Sharma, D. (2009). Human Resource Development: Maxford Books.

Smither, J. W. (1998). Performance appraisal: State of the art in practice: Jossey-Bass Publishers.

Srinivasa Rao, D. A. (2007). Effectiveness of performance management systems: an empirical study in Indian companies. The International Journal of Human Resource Management, 18(10), 1812-1840.

Strauss, G. (2001). HRM in the USA: correcting some British impressions. International Journal of Human Resource Management, 12(6), 873-897.

Virmani, B. R., \&Guptan, S. U. (1991). Indian management: Vision Books New Delhi.

Wilson, J. P., \& Western, S. (2000). Performance appraisal: an obstacle to training and development? Journal of European Industrial Training, 24(7), 384-391. 